\title{
The Beginnings of Political and Economic Relations between Albania and Italy
}

\author{
Paulin Marku \\ "Sapienza" University, Rome, Italy
}

\section{Doi:10.5901/ajis.2013.v2n11p24}

\section{Abstract}

After the revolution of June 1924 and its suppression in Albania were found in December 1924 before a delicate economic political situation. So it was necessary to be supported from a strong state economically. Given the impact that had Yugoslavia in December 1924 the approach with this state was normal and so it happened. But soon the intervention of Yugoslavia in the country's politics by soured relations which led Prime Minister Ahmed Zogu to the demolition of relations with Yugoslavia. This situation cannot be left unnoticed by the greedy Albanian territory. This delicate moment was used well by Mussolini who offered economic aid and promising territorial protection that will not interfere at all in Albanian domestic policy although later proved otherwise. Economic and political relations between Albania and Italy were materialized through two treaties of Tirana 1926 and 1927, which began a new era in bilateral relations between Albania and Italy which would be more in the course of defining state.

The Dukagjini's revolt alienated more the relations between Albania and Yugoslavia, bringing Ahmet Zog toward an agreement with Italy. The intentions of Yugoslavia to interfere in Albanian politics had failed. ${ }^{1}$ (Paskal Milo, 1992) On January 1926, France proposed the signing of a security pact among France, Italy and Yugoslavia which would stop the expansion of Italy in Balkans. Before this pact, Mussolini proposed another pact which was visibly beyond the France and Jugoslavia interests. Thus, Mussolini sent to Albania Alessandro Lessona to concretely discuss with Ahmet Zogu for the signing of a bilateral pact, because according to him, the strengthening of Albania would come as a consequence of the strengthening of Italian politics. ${ }^{2}$ (Bernd J Fischer, 1995) After many attempts and discussions there was made possible to sign a friendship and security bilateral pact between Italy and Albania on November 27, 1926 known internationally as "The first pact of Tirana". The pact consisted of 5 points and was signed by the minister of the foreign affairs Hysen Vrioni and the Italian ambassador in Tirana Pompeo Aloisi. The first point of the pact sanctioned that; Italy and Albania declared that any political, legal and territorial violation of Albania was contrary to the bilateral interests. It was in the interest of both parts that the signers would not do any military or political agreement with other countries to the detriment of one of the signing parties.

Through a telegram, Ahmet Zogu greeted the Italian King and decorated him with "The largest cordon of national order", meanwhile Vitorio Emanuele III replied with courtesy the greeting. ${ }^{3}$ (Arkivi Qendror i Shtetit, 1926). The pact was ratified in Rome on January 25, 1925, it was considered as secret and was registered in the League of Nations on February 8, 1927 with no 1402 , publication LX pg. 15. ${ }^{4}$ (Amedeo Giannini, 1940). Even though Franca an Yugoslavia did not like this pact they did not do any visible movement against it. The only state that opposed this pact was soviet union which called this agreement as "enslaver". Albanian diasporas was against this pact too. Because of the signing of this pact, the foreign minister of Yugoslavia Nincic quitted on December 7, 1926, by causing the dissolution of the government some days later. The well-known politician as anti Albanian Nikola Pasic died angry on December 10, $1926 .{ }^{5}$ ( Kastriot Dervishi, 2006)

Following this, the Yugoslav parliament did not ratified the treaty of commerce and navigation with Albania, voted firstly by the deputies room on November 6,1926 . This treaty was especially useful for the border areas.

\footnotetext{
1 Paskal Milo: Shqiperia dhe Jugosllavia (1918 - 1927). Enciklopedike. Tirana 1992. pg. 338.

2 Bernd J Fischer: Mbreti Zog dhe perpjekja per stabilitet ne Shqiperi. Cabej. Tirana 1995. pg.105.

${ }^{3}$ Arkivi Qendror i Shtetit. Tirana (A.Q.SH.).Gazeta e Korces 18 dicembre 1926.

${ }^{4}$ Amedeo Giannini: L'Albania dall'indipendenza all'Unione con l'Italia. Varese 1940. pg. 171.

${ }^{5}$ Kastriot Dervishi. Historia e shtetit shqiptar 1912-2005. Edit. 55 Tirana 2006. pg.262. 
After the end of the year 1926 events the Albanian Yugoslav relations were going to a major irritation. A fact that sped irritation was the arrest of Albanian Montenegro Vuk Gjuraskovic and his collaborators, Kristo e Lipi Dhorit, Abdulla Kalaja and Ligor Cerepi. Vuk Gjuraskovic was accused by the Ministry of internal affairs as Yugoslav security agent. ${ }^{6}$ (Bernd J Fischer, 1995) Belgrade reacted quite strongly demanding his immediate release through a communication on May 30, 1927. ${ }^{7}$ (Paskal Milo, 1992) A pro Yugoslav position kept the Albanian ambassador in Belgrade, Ceno Kryeziu. After several unsuccessful negotiations to Yugoslavia withdrew its embassy in Tirana. In addition Yugoslavia closed even the consulates it had in Vlora, Shkodra and Korca. In this conditions Ahmet Zogu closed the Albanian embassy in Belgrade, charging the Italian embassy to protect Albanians rights there.

The resolving of this interstate conflict was made through the intervention of France, Italy, Great Britain and Germany. In August 1927 there were restored the diplomatic relations between Albania and Yugoslavia. Yet another fact will again aggravate these relations, just the assassination of former Albanian ambassador in Belgrade, Ceno Kryeziu. ${ }^{8}($ Arben Puto, 2009) According to British diplomatic sources between him and Ahmed Zogu had started a political controversy. On October 14, 1927 a young man from Elbasan Alqivadh Bebi shot with three bullets in the head Ceno Kryesziu in Prague. The gun man surrendered himself to police and in cold blood situation he said he had just arrived in Prague to perform that murder.

The Yugoslav press accused for the murdering of Kryeziu directly the opponents of Yugoslav-Albanian friendship. While on the other hand comes the immediate rejection of the Albanian authorities who categorically denied their involvement in the murder. ${ }^{9}$ (Kastriot Dervishi, 2006)

The killing of Ceno Kryeziu impacted further in the improvements of the Italy - Albanian relations. 5 weeks after the murder there was signed this pact that has entered in history as "The Second Pact of Tirana". This was a defensive alliance between Italy and Albania, which was registered in the League of Nations in January 3, 1928. The pact was signed by Minister of Foreign Affairs of Albania lljaz VRIONI and Italian Ambassador in Albania, Ugo Sola. ${ }^{10}(P$. Pastorelli, 1967)

The pact consisted of 7 points and was contradistinction against the a security pact between France and Yugoslavia. All previous agreements between Italy and Albania in the League of Nations, after the acceptance of Albania, will accurately and faithfully be respected. This alliance had a term of 20 years. Under this pact if one party went to war and the other part would go to war too. After signing the pact, Senate gave to Ahmed Zogu the title "Savior of the fatherland".

\footnotetext{
${ }^{6}$ Bernd J Fischer: Mbreti Zog dhe perpjekja per stabilitet ne Shqiperi. Cabej. Tirana 1995. pg.135.

7 Paskal Milo: Shqiperia dhe Jugosllavia (1918 - 1927). Enciklopedike. Tirana 1992. pg. 339.

${ }^{8}$ Arben Puto: Shqiperia politike 1912 - 1939. Toena. Tirana 2009. Pg416.

${ }^{9}$ Kastriot Dervishi. Historia e shtetit shqiptar 1912-2005. Edit. 55 Tirana 2006. pg.263.

10 P. Pastorelli: Italia e Albania 1924 - 1927 Firenze 1967. pg. 180. 